Portland State University

PDXScholar

Summer 2021

\title{
Examination of Exhaustion in Larval Pacific Lamprey (Entosphenus Tridentatus) Through Variations of Temperature, Flow, and Cover
}

Jessica Falcon

Follow this and additional works at: https://pdxscholar.library.pdx.edu/honorstheses

Part of the Animal Sciences Commons

Let us know how access to this document benefits you.

Recommended Citation

Falcon, Jessica, "Examination of Exhaustion in Larval Pacific Lamprey (Entosphenus Tridentatus) Through Variations of Temperature, Flow, and Cover" (2021). University Honors Theses. Paper 1142.

https://doi.org/10.15760/honors.1173

This Thesis is brought to you for free and open access. It has been accepted for inclusion in University Honors Theses by an authorized administrator of PDXScholar. Please contact us if we can make this document more accessible: pdxscholar@pdx.edu. 
Examination of exhaustion in larval Pacific lamprey (Entosphenus tridentatus) through variations of temperature, flow, and cover

by

\section{Jessica Falcon}

An undergraduate honors thesis submitted in partial fulfillment of the

requirements of the degree of
Bachelor of Science
in
University Honors
and
Biology

Thesis Adviser

Timothy A. Whitesel

Portland State University 


\begin{abstract}
Pacific lampreys (Entosphenus tridentatus) are culturally and ecologically valuable throughout the western coast of North America. The larval (ammocoete) stage of the Pacific lamprey spends three to eight years burrowed in the sediment as a filter feeder, and is an essential contributor to many of the Northwest's freshwater ecosystems. Larval lamprey may be vulnerable to warming waters caused by climate change as well as seasonal dredging and salvaging events that dislodge lamprey from sediment, as they prefer cooler water and are relatively poor swimmers in comparison to other fish such as salmon. In this study, we observed how lamprey may become exhausted by these conditions by analyzing the burrowing behavior of 63 larval Pacific lamprey after exposure to treatment combinations of temperature, flow, and burrowing ability. We found that larvae that were unable to burrow during treatments exhibited signs of exhaustion, and that lamprey exposed to warmer temperatures moved more quickly than lamprey in colder treatments. Metrics for turbulent flow did not show differences between groups, and there did not appear to be significant interactions between combinations of temperature, flow, and cover. These results suggest that lamprey may be able to tolerate warming waters resulting from climate change for shorter periods of time, and that an inability to burrow into substrate may quickly lead to exhaustion regardless of turbulent flow presence. These findings may aid in management actions for conservation efforts for Pacific lamprey, including summertime salvage events.
\end{abstract}




\section{INTRODUCTION}

Pacific lampreys (Entosphenus tridentatatus) are culturally and ecologically valuable throughout their distribution, which extends throughout much of the Pacific Ocean and is heavily concentrated along the western coast of North America (see Renaud, 2011). In the Columbia River Basin, Native American tribes such as the Nez Perce Tribe and Confederated Tribes of the Umatilla Indian Reservation value Pacific lamprey for nourishment and medicinal use (Close et al., 2002). Pacific lamprey are also of immense ecological importance. Pacific lampreys are born in freshwater, and remain in freshwater during their larval (ammocoete) stage of life, which lasts between three and eight years (see Clemens et al., 2019; Dawson et al., 2015b). During this time, Pacific lamprey larvae are blind and remain mostly burrowed in the sediment as filter feeders, consuming detritus and other organic materials through nutrient processing and cycling (Close et al., 2002). Their extensive biomass serves as a food source and buffer for a wide variety of predators (see Wang and Schaller, 2015; Arakawa and Lampman, 2020), making them an integral part of the Northwest's freshwater food webs. After undergoing a metamorphosis, newly emerged juvenile (macrophthalmia) Pacific lamprey emigrate to the Pacific Ocean, where they continue to grow and parasitize other fish for a period of time. Adults return to freshwater to spawn, and die shortly after (see Close et al., 1995; Kostow 2002; Clemens et al., 2019).

The evident decline in abundance of Pacific lamprey throughout many parts of their distribution (see Close et al., 2002; Kostow, 2002; Wang and Schaller, 2015) has sparked concern among tribes and federal agencies alike, and collectively led to the petitioning of Pacific lamprey, western brook lamprey (Lampetra richardsoni), and river lamprey (Lampetra ayresii) as

candidates for the Endangered Species Act in 2003 (USFWS, 2004). However, a lack of information led to the denial of the petition (USFWS, 2004). Collaborative management efforts 
and continual status assessments have led to the creation of the Pacific Lamprey Conservation Initiative (see USFWS 2012), which has consequently heightened the need for further understanding of this species.

Causes for the decline of Pacific lamprey include water pollution, streamflow management, dewatering events, dredging events, habitat loss, barriers to fish passage, and warming waters caused by climate change (Close et al., 1995; Harris et al., 2020; Wang et al., 2020). Warming waters may be especially detrimental to Pacific lamprey of all life stages, as their ectothermic nature is regulated by external water temperature. Many stream temperatures throughout the Columbia River Basin (USA) are projected to increase by more than $5^{\circ} \mathrm{C}$ in the summer months by the end of the 21 st century (Ficklin et al., 2014). Resulting temperatures may reach or exceed $27^{\circ} \mathrm{C}$ to $29^{\circ} \mathrm{C}$ during the summer months, exposing Pacific lamprey to sublethal or lethal temperatures in many areas (Uh and Whitesel, 2017), further exacerbating their decline.

The longest life stage for Pacific lamprey is the larval stage, lasting up to eight years (see Clemens et al., 2019; Dawson et al., 2015). Threats that are of particular concern for the Pacific lamprey's larval stage are those which may eject larvae from the sediment into high velocity waters, such as dredging events, in which they may struggle to swim and be vulnerable to predation (see Close et al., 2002, Dauble et al., 2006, \& Arakawa and Lampman, 2020). Dislodgement from stream sediments may also make it difficult for larvae to avoid entrainment, as larval lamprey swimming ability is relatively poor in comparison to other fish such as salmon (Sutphin and Heuth, 2010). As such, larval lamprey find refuge in the sediments from both predators and high flow conditions.

Previous studies have explored ways to prevent larval lamprey mortality caused by various factors. Conservation efforts of Pacific lamprey currently include alterations to hydroelectric dams 
to accommodate lamprey passage, decreasing drain rates during dewatering events, and increased spatial variability of habitats (see Bracken and Lucas 2013; Clemens et al., 2017; Liedtke et al., 2015; Harris et al., 2020). However, it is still unclear how relatively warm temperatures and extensive swimming affect larval Pacific lamprey, and whether or not the combination of these factors may work together to create exhaustive conditions. It is evident that water temperatures will continue to increase in the future due to climate change, and existing literature suggests that larval lamprey may be negatively affected by this (Wang and Schaller, 2015). Additionally, larvae may be negatively affected by turbulent waters, as they do not swim well (Sutphin and Heuth, 2010). Burrowing can provide refuge for lamprey in both warming (Whitesel, unpublished data) and turbulent waters. However, it is unclear how managers should take these aspects of lamprey biology into account during conservation and management actions. For example, habitat restoration and dam maintenance projects often take place during the warmest months. These efforts are often preceded by salvage efforts which involve the displacement of larvae from burrows, ejecting them into the water column where they must swim. Whether or not larval lamprey can tolerate these actions or if they lead to exhaustion is unclear.

The goal of this study is to determine how vulnerable larval Pacific lamprey are to warmer temperatures, specifically when they need to swim actively, for both conservation and management purposes. The objectives of this study were to determine whether or not larvae exhibit signs of exhaustion as a result of heat exposure, exposure to flowing water, and the inability to burrow, or a combination of these factors. 


\section{METHODS}

\section{$\underline{\text { Collection }}$}

Larval Pacific lamprey were collected from Cedar Creek, Washington (USA), a tributary to the Lewis River, using an ABP-2 backpack electrofisher on April 22, 2021 [see Ostberg et al., 2019 for settings]. This area is home to both Pacific lamprey and western brook lamprey. Larvae were identified based on morphological characteristics (Docker et al., 2016), after being anesthetized as described in Ostberg et al. (2019). Larvae were measured and if they met a minimum size requirement for identification (of total length $\geq 70 \mathrm{~mm}$; Docker et al., 2016), then they were identified. Larval Pacific lamprey were retained and held in one of two aerated buckets containing stream water and cover. Lamprey were then transported for 60 minutes to the Columbia River Fish and Wildlife Conservation Office (CRFWCO) in Vancouver, Washington (USA). Once at CRFWCO, fish from each bucket were randomly assorted equally into two separate $37.9 \mathrm{~L}$ acclimation aquariums $(51.1 \times 25.7 \times 31 \mathrm{~cm})$, containing approximately $7.5 \mathrm{~cm}$ of river sand from the Columbia River and $17.5 \mathrm{~cm}$ of spring water from Columbia Springs Vancouver Trout Hatchery in Vancouver, Washington (USA) chilled to temperatures matching that of Cedar Creek at the time of collection. Evaporation was compensated for by refilling the aquariums as needed with distilled and deionized water. Lamprey were acclimated to captivity and final treatment temperatures over twelve days. Lamprey were also placed under a gradually progressing photoperiod during this time, starting at 13 hours and 55 minutes of light (natural photoperiod at time of collection) and progressing to 16 hours and 55 minutes of light (natural photoperiod of June 21), at a rate of 15 minutes every two days. Larvae were acclimated gradually to one of two experimental temperatures: half the lamprey to $18^{\circ} \mathrm{C}$, and the other half to $27^{\circ} \mathrm{C}$, at average rates of $0.75^{\circ} \mathrm{C} /$ day and $1.5^{\circ} \mathrm{C}$ /day, respectively. Both aquaria were then held 
at final treatment temperatures and photoperiod for an additional 11 days for a total period of 23 days. Lamprey were fed every four days of the 23 day period, starting on day five of acclimation and ending on day 21 of the acclimation period. During feeding, each acclimation aquarium was given a slurry mixture of $0.43 \mathrm{~g}$ of yeast and $0.11 \mathrm{~g}$ of salmon analog for the first feeding session, and subsequently given $0.50 \mathrm{~g}$ of salmon analog during each feeding thereafter (see Jolley et al., 2015).

\section{$\underline{\text { Treatments }}$}

Experimental treatments included permutations of three variables: temperature $\left(27^{\circ} \mathrm{C}\right.$ or $\left.18^{\circ} \mathrm{C}\right)$, turbulent flow $(+\mathrm{T}$ or $-\mathrm{T})$, and the ability to burrow into substrate $(+\mathrm{B}$ or $-\mathrm{B})$. Chronic treatments (11 days) were at final treatment temperatures $\left(27^{\circ} \mathrm{C}\right.$ or $\left.18^{\circ} \mathrm{C}\right)$ while the acute treatments (120-240 min) were turbulent flow and burrowing (T, B). Assortment of lamprey into acute treatment tanks corresponded with chronic treatment temperatures, for a total of six treatment conditions. For example, all lamprey reared at $18^{\circ} \mathrm{C}$ were only placed in acute treatment tanks that were also $18^{\circ} \mathrm{C}$, and the same concept applied for the $27^{\circ} \mathrm{C}$ group. After 11 days of constant exposure to treatment temperatures, larvae were randomly assorted into six acute treatment tanks. Lamprey were transferred to acute treatment tanks between 0800 and 1000 hours. Lamprey were held in acute treatments for 120-240 minutes. All six treatments can be seen in Table 1. Larvae from both acclimation aquariums were randomly assorted into one of three acute treatment tanks on May 15th, 2021. This process was repeated on May 18th, 2021.

Temperature Treatment: Chronic-We evaluated two temperature treatments. After acclimation, larvae were held at temperatures of either $27^{\circ} \mathrm{C}$ or $18^{\circ} \mathrm{C}$ for 11 days. Treatment temperatures were maintained using a digital heater to warm the water temperature $\left(27^{\circ} \mathrm{C}\right)$ or ambient room temperature $\left(18^{\circ} \mathrm{C}\right)$. 
Turbulence Treatment: acute—Six additional tanks were used to generate turbulent flow treatments. All turbulent flow treatment tanks consisted of $37.9 \mathrm{~L}$ aquariums $(51.1 \times 25.7 \times 31.0$ $\mathrm{cm}$ ) containing approximately $7.5 \mathrm{~cm}$ of creek sand and approximately $16.5 \mathrm{~cm}$ of spring water. Tanks were wrapped in dark plastic with a cover to simulate shaded conditions and minimize light penetration and water evaporation. In three of the tanks, turbulence $(+\mathrm{T})$ was created using aquarium pumps to recirculate the water. Water was pumped from near the substrate surface at one end of the tank, guided through a plastic aqueduct to the opposite end of the tank where it was returned at the surface of the water. Water was recirculated at a rate of approximately 3700 $\mathrm{mL} / \mathrm{min}$ for tanks with $+\mathrm{T}$ treatments (Figure 1), creating a turbulent flow throughout the tank. In the remaining three tanks, $-\mathrm{T}$ conditions were created by adding filters and aqueducts as described in $+\mathrm{T}$ treatments, but filters remained off for the entirety of the experiment.

Burrowing Treatment: acute-The same six tanks used to generate turbulent flow treatments were also used to generate burrowing treatments. Three treatment tanks that prevented larvae from burrowing into the sediment (-B), were created using a $1.5 \mathrm{~mm}$ pore-size screen (secured with a steel bar frame) to cover the sand. Mesh screening was folded upwards and partially covered the sides and corners of the aquaria glass to aid in prevention of burrowing (Figure 2). The remaining three treatments that permitted burrowing $(+\mathrm{B})$ were provided with a small roll of mesh screening in the corner, but mesh did not cover the sand and was not secured down with a steel frame.

\section{Burrowing Trials}

To determine whether treatment conditions influenced the larvae, we evaluated their burrowing behavior. Burrowing trials were conducted in two $39.7 \mathrm{~L}$ burrowing aquariums each containing approximately $15 \mathrm{~cm}$ of river sand covered by approximately $10 \mathrm{~cm}$ of spring water. 
One burrowing aquarium was held at $18^{\circ} \mathrm{C}$ and one at $27^{\circ} \mathrm{C}$ to match temperature treatments of lamprey. After final exposure to acute treatments, lamprey were gently agitated from the sand and then netted randomly, one at a time, from treatment tanks and placed into a staging chamber. The staging chamber was positioned directly over a burrowing chamber connected by a ball valve and plastic tubing (11.5 cm long x $1.5 \mathrm{~cm}$ diameter) (Figure 3).

Larvae were allowed to rest in the staging chamber for approximately four minutes (see Quintella et al. 2007; Dawson et al. 2015) after which the ball valve was slowly opened to allow larvae to directly enter a burrowing chamber. The burrowing chamber was a clear, perforated acrylic rectangular prism ( $31 \times 18 \times 12 \mathrm{~cm})$ without a top or bottom (see Quintella et al., 2007; Dawson et al., 2015a). The burrowing chamber was placed in the center of the burrowing aquarium such that, once a larva started burrowing it could burrow completely without encountering any obstacles (e.g. aquarium walls), (as in Quintella et al., 2007). Other than matching treatment and burrowing trial temperatures, individual lamprey were moved randomly from the treatment tanks (alternating temperature treatments) to a staging chamber.

Individual larvae were given 15 min to completely burrow (body withdrawn completely under the sand). If a larva completed burrowing it was removed from the burrowing tank. If a larva did not attempt to burrow within $10 \mathrm{~min}$ the trial was terminated and it was removed from the tank. If a larva had initiated burrowing within $10 \mathrm{~min}$, they were given an additional five minutes to complete burrowing, after which the trial was terminated. All burrowing trials were recorded on video.

For all burrowing trials, four metrics were quantified (see Dawson et al., 2015a): (1) the total time lamprey were active during burrowing, (2) the total time lamprey were inactive during burrowing (total time stopped), (3) the number of stops (no active movement for $>1$ second), 
and (4) the total time to burrow, measured from when a larva initiated its final attempt to burrow to when the burrowing was completed and the body was no longer visible from the surface. All times were measured to the nearest $0.1 \mathrm{sec}$.

$\underline{\text { Analysis }}$

To evaluate whether temperature, turbulent flow, burrowing, and various combinations of these variables affected larval behavior, we made eight planned comparisons between our six treatments (Table 1). Seven (10\%) of the larvae did not burrow, this behavior was not different between any treatment group (Fisher's Exact Test, $\mathrm{P}>0.10$ ), and these larvae were omitted from subsequent analyses. All remaining data (63 larvae) was analyzed using a Mann-Whitney U test. Since we chose to maximize treatment combinations which resulted in relatively small sample sizes per treatment and reduced statistical power, significance was accepted at alpha $=0.10$. After a Bonferroni correction for the planned comparisons, the adjusted alpha for significance was 0.0125 . Since the metrics in the eight planned comparisons were not significantly different, the data for temperature, turbulent flow and burrowing ability, respectively, was pooled for subsequent analysis. Pooled data was used to make three additional planned comparisons. After a Bonferroni correction for these planned comparisons, the adjusted alpha for significance was 0.0333 .

\section{RESULTS}

72 Pacific lamprey larvae were collected from Cedar Creek, WA. Larvae lengths ranged from $71 \mathrm{~mm}$ to $119 \mathrm{~mm}$. Creek temperature during the time of collection was $9^{\circ} \mathrm{C}$. Aquarium temperatures during acclimation, treatment, and burrowing trials were maintained within 1 degree of target temperature for the $27^{\circ} \mathrm{C}$ aquarium (Figure 4), and within 2 degrees of target 
temperature for the $18^{\circ} \mathrm{C}$ aquarium (Figure 5). There were no mortalities of larval lamprey during the acclimation period or during the temperature treatment. On May 15th, half the lamprey were transferred from chronic treatments to acute treatments $\left(\mathrm{n}=18\right.$ from $18^{\circ} \mathrm{C}, \mathrm{n}=18$ from $\left.27^{\circ} \mathrm{C}\right)$. This process was repeated on May 18th, $2021\left(\mathrm{n}=16\right.$ from $18^{\circ} \mathrm{C}, \mathrm{n}=18$ from $27^{\circ} \mathrm{C}$ ). Two mortalities occurred between the first and second rounds of burrowing trials in the $18^{\circ} \mathrm{C}$ temperature treatment tank, possibly as a result of stress caused from removing the first set of burrowing trial larvae. Dissolved oxygen levels were monitored at least twice a week during the acclimation and testing periods, and ranged between 4.6 and $10.4 \mathrm{mg} / \mathrm{L}$ in both acclimation aquariums.

We made eight planned comparisons between combinations of temperature, turbulent flow, and burrowing ability to determine differences in burrowing performance. In general, all burrowing metrics (active time, inactive time, total time, and number stops) were similar between treatments. We made the following eight, planned comparisons: $+\mathrm{T} /+\mathrm{B} / 18^{\circ} \mathrm{C}$ to $+\mathrm{T} /+\mathrm{B} / 27^{\circ} \mathrm{C},+\mathrm{T} /-\mathrm{B} / 18^{\circ} \mathrm{C}$ to $+\mathrm{T} /-\mathrm{B} / 27^{\circ} \mathrm{C},-\mathrm{T} /-\mathrm{B} / 18^{\circ} \mathrm{C}$ to $-\mathrm{T} /-\mathrm{B} / 27^{\circ} \mathrm{C},+\mathrm{T} /+\mathrm{B} / 18^{\circ} \mathrm{C}$ to $+\mathrm{T} /-\mathrm{B} / 18^{\circ} \mathrm{C}$, $+\mathrm{T} /-\mathrm{B} / 18^{\circ} \mathrm{C}$ to $-\mathrm{T} /-\mathrm{B} / 18^{\circ} \mathrm{C},+\mathrm{T} /+\mathrm{B} / 27^{\circ} \mathrm{C}$ to $+\mathrm{T} /-\mathrm{B} / 27^{\circ} \mathrm{C},-\mathrm{T} /-\mathrm{B} / 18^{\circ} \mathrm{C}$ to $-\mathrm{T} /-\mathrm{B} / 27^{\circ} \mathrm{C}$, and $+\mathrm{T} /-$ $\mathrm{B} / 27^{\circ} \mathrm{C}$ to $-\mathrm{T} /-\mathrm{B} / 27^{\circ} \mathrm{C}$ (Table 2$)$. The single exception to this was a significant difference $(\mathrm{P}=$ $0.0009)$ in active time between treatments $-\mathrm{T} /-\mathrm{B} / 18^{\circ} \mathrm{C}$ and $-\mathrm{T} / \mathrm{-B} / 27^{\circ} \mathrm{C}$. Overall, treatment active times ranged from $4.90-67.80$ seconds $($ median $=22.93 \mathrm{~s})$, inactive time ranged from $0-84.35$ seconds $($ median $=17.70 \mathrm{~s})$, total burrowing time ranged from $9.27-138.20$ seconds $($ median $=$ 40.49s), and number of stops during final burrow attempts ranged from $0-7$ stops (median $=3$ stops). Given this result, we pooled data into three planned comparisons between burrowing ability, temperature, and turbulent flow. Larvae that were unable to burrow during treatments (B) showed more inactive time (median $=27.46 \mathrm{~s}, \mathrm{P}=0.0029$ ), took more total time to burrow 
(median $=50.40 \mathrm{~s}, \mathrm{P}=0.018)$, and a made a greater number of stops while burrowing (median $=$ 3.5 stops, $\mathrm{P}=0.011$ ) than larvae who were able to burrow $(+\mathrm{B})$ (Figure 6 and $6 \mathrm{a}$ ). Active burrowing time did not differ between $-\mathrm{B}$ and $+\mathrm{B}$ larvae. Larvae reared at $18^{\circ} \mathrm{C}$ spent significantly more time being active during burrowing trials (median $=28.47 \mathrm{~s}, \mathrm{P}=0.0015$ ) and took significantly longer to burrow (median $=58.83 \mathrm{~s}, \mathrm{P}=0.0300$ ) than those reared in $27^{\circ} \mathrm{C}$ (Figure 7 and 7a). All burrowing metrics for larvae that experienced turbulent flow $(+\mathrm{T})$ or no flow $(-\mathrm{T})$ were similar $(\mathrm{P}>0.0333)$ (Figure 8 and $8 \mathrm{a}$ ).

\section{DISCUSSION}

This study demonstrates that larvae unable to burrow in substrate may become exhausted quickly, and that burrowing may aid in the prevention of exhaustion. Lamprey that were not able to burrow for up to 120-240 minutes during treatments were more inactive, took more total time to burrow, and stopped (or rested) more once they were allowed to burrow than those that were always able to burrow. This suggests that the inability to burrow led to larvae becoming tired and struggling to burrow when given the opportunity. This is consistent with previous research observing lamprey ventilation (Potter and Rogers, 1972) as well as the metabolic recovery of sea lamprey after vigorous exercise (Wilkie et al., 2001). These studies found that larvae that were able to burrow consumed less oxygen after exercise and demonstrated that the act of burrowing has a calming effect on larvae in post-exercise conditions. This suggests that larval Pacific lamprey which were not able to burrow during this study may have consumed oxygen at higher rates than those that could burrow. Thus, it is reasonable to conclude that the inability to burrow is exhausting to larval lamprey. It is unclear whether the larvae that were not able to burrow swam constantly or simply lay on the substrate surface. For example, this exhaustion may result 
from extensive exercise (such as continually swimming and searching for a burrowing opportunity) or stress from not being able to burrow, or both. We accounted for this factor by adding turbulent water to some treatments to stimulate lamprey movement. However, it is possible that tank structure may have been such that larvae could rest periodically.

Our findings from this study also indicate that lamprey exposed to sublethal temperatures may not experience adverse effects after 11 days of exposure. These findings are supported through comparisons of active times and total times between temperature treatments, showing that lamprey exposed to warmer temperatures $\left(27^{\circ} \mathrm{C}\right)$ burrowed more quickly than lamprey at $18^{\circ} \mathrm{C}$. A previous study by Uh and Whitesel (2017) found similar results by demonstrating that Pacific lamprey larvae were able to survive after 30 days of exposure to $27^{\circ} \mathrm{C}$. It is possible that, with faster burrowing times than at $18^{\circ} \mathrm{C}$, lamprey movement in $27^{\circ} \mathrm{C}$ was more efficient. As Pacific lamprey are ectotherms, their internal body temperature is directly affected by external temperatures, and movement speed may be increased by increasing temperatures (see Temple and Johnston, 1997; Claireaux et al., 2006; Riyanto et al., 2013). Other research measuring movement speeds of sea bass (Claireaux et al., 2006) and jack mackerel (Riyanto et al., 2013) noted similar correlations between increased temperature and increased movement speeds. Alternatively, Uh and Whitesel (2017) observed behavior consistent with exhaustion after rearing larvae for 30 days in $27^{\circ} \mathrm{C}$, whereas the rearing period for this study was less than half that time (11 days). Uh and Whitesel (2017) reported more inactive time and more stops for lamprey reared at $27^{\circ} \mathrm{C}$ when compared to $21^{\circ} \mathrm{C}$, suggesting a level of exhaustion at warmer temperatures that we did not observe. It is possible that relatively short exposure times may not result in exhaustion. In natural environments, larvae normally are unlikely to be exposed to peak 
annual temperatures for longer than 14 days (see Merz et al., 2019), so it is possible that Pacific lamprey may be able to avoid exhaustion in these conditions.

Turbulent flow does not appear to lead to exhaustion in larval lamprey. This is emphasized by the lack of any difference in burrowing behavior between larvae that were exposed to turbulence and those that were not. This finding was unexpected. The inability of larval and juvenile Pacific lamprey to sustain necessary swimming speeds in high velocity waters when emerged from burrows has been previously considered in management actions (see Dauble et al., 2006; Bracken and Lucas, 2013). Additionally, larval lamprey are considered poor swimmers (Sutphin and Heuth, 2010; McClellan et al. 2016) that cannot swim for long periods of time without experiencing exhaustion (Wilkie et al., 2001). Flow rates in Sutphin and Heuth (2010) were also greater than in this study, so it is also possible that turbulent flow in this study was not strong enough to cause exhaustion. Pockets of low flow may have also existed within the aquaria. Normally, the cover that burrowing substrate provides is adequate in preventing lamprey exhaustion by protecting lamprey from feeling the effects of high velocity waters.

Burrowing ability, temperature, and turbulent flow did not appear to interact in a manner that led to exhaustion. Based on existing knowledge of Pacific lamprey burrowing behavior after exercise, swimming ability, and temperature exposure, (see Wilkie et al., 2001; Sutphin and Heuth, 2010; Uh and Whitesel, 2017) we predicted that we would be most likely to observe exhaustion in warmer temperatures that had a high rate of turbulent flow and an inability to burrow $\left(27^{\circ} \mathrm{C} /+\mathrm{T} /-\mathrm{B}\right)$ when compared to $\left(18^{\circ} \mathrm{C} /-\mathrm{T} /+\mathrm{B}\right)$. We did see a difference between these treatments, but it is likely that these findings are insignificant due to small sample size and low power $(\mathrm{n}=6, \mathrm{n}=11$, respectively). As such, small sample size and low power may have affected other treatment groups. Alternatively, increased exposure to sublethal temperatures as noted in 
Uh and Whitesel (2017) could have allowed a difference in results, as well as the greater flow rates noted in Sutphin and Heuth (2010). Insignificant findings for un-pooled comparisons may have resulted from a lack of control over other variables that affect exhaustion, such as oxygen consumption and partial cover conditions. Nonetheless, results from individual variables specifically (temperature, flow, burrowing ability) indicate that lamprey mortality may increase in warmer, non-burrowing conditions. Increased temperature conditions stimulate further lamprey exercise, and existing knowledge of larval exercise is likely unsustainable for longer periods of time (see Wilkie et al. 2001; Sutphin and Heuth, 2010).

It is important to consider how larval Pacific lamprey may be affected by temperature, turbulent flow, and burrowing ability in order to further understand how to improve conservation and management actions. Despite a changing climate and warming streams, Pacific lamprey larvae may be able to manage increased water temperatures as high as $27^{\circ} \mathrm{C}$ for relatively short periods of time. Additionally, increased water temperature that occurs during summertime salvage events may not be problematic. However, the inability to burrow can quickly become exhaustive to larvae if they are unable to re-burrow quickly, even in conditions where turbulent flow is not present. For example, exhaustion of lamprey may be prevented by adding sediment to lamprey holding vessels (e.g. a bucket or cooler) during collection and movement, so that lamprey can burrow. Whether temperature and the need to swim actively may interact relative to exhaustion remains unclear. Conservation efforts for Pacific lamprey may additionally benefit from further research on how warm temperatures and active swimming may interact. 


\section{FIGURES}

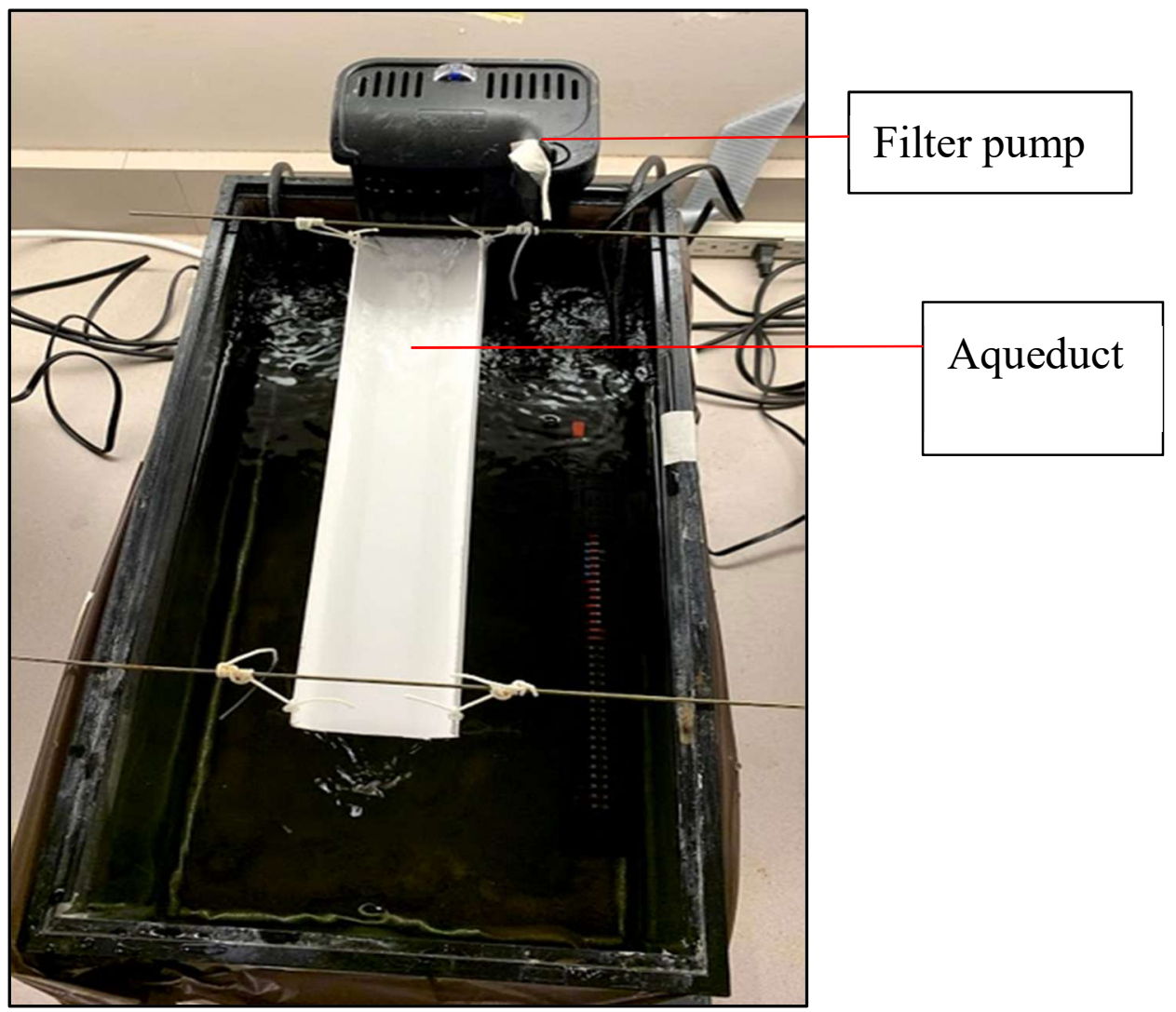

Figure 1: Aqueduct used to create turbulent flow by pumping water from the filter at one end of the tank and moving it to the other end of the tank. Intake from the filter occurred near the substrate surface and circulated water throughout the tank to create turbulent flow conditions. 


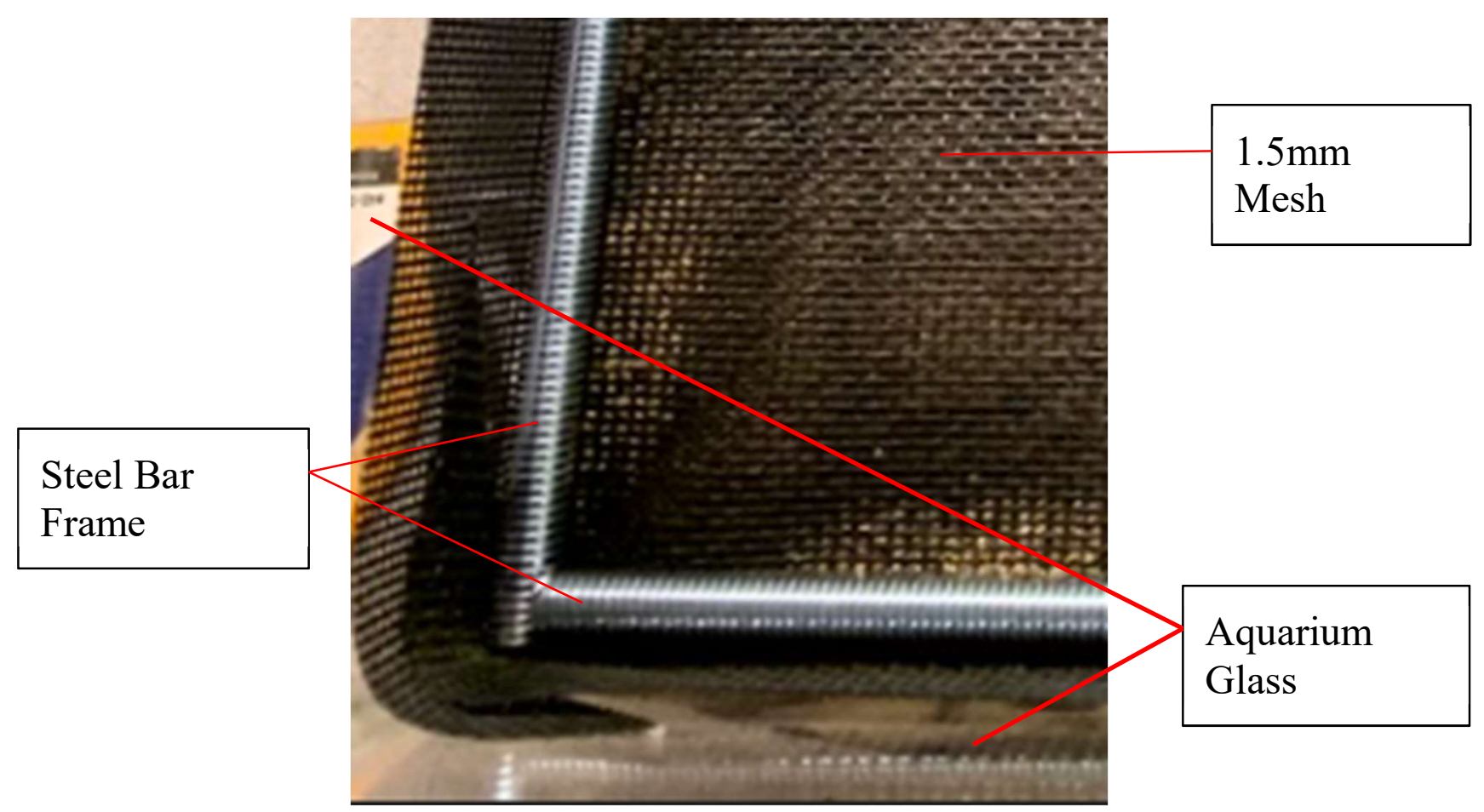

Figure 2: Mesh screening (1.5 $\mathrm{mm}$ pore-size) used to prevent lamprey from burrowing conditions. Mesh was raised approximately one to two inches along the sides to ensure coverage of the sand and was tightly secured with a steel bar frame. Figure view is zoomed in at the corner of the tank to show fitting of steel bars and mesh in the aquarium corner. 


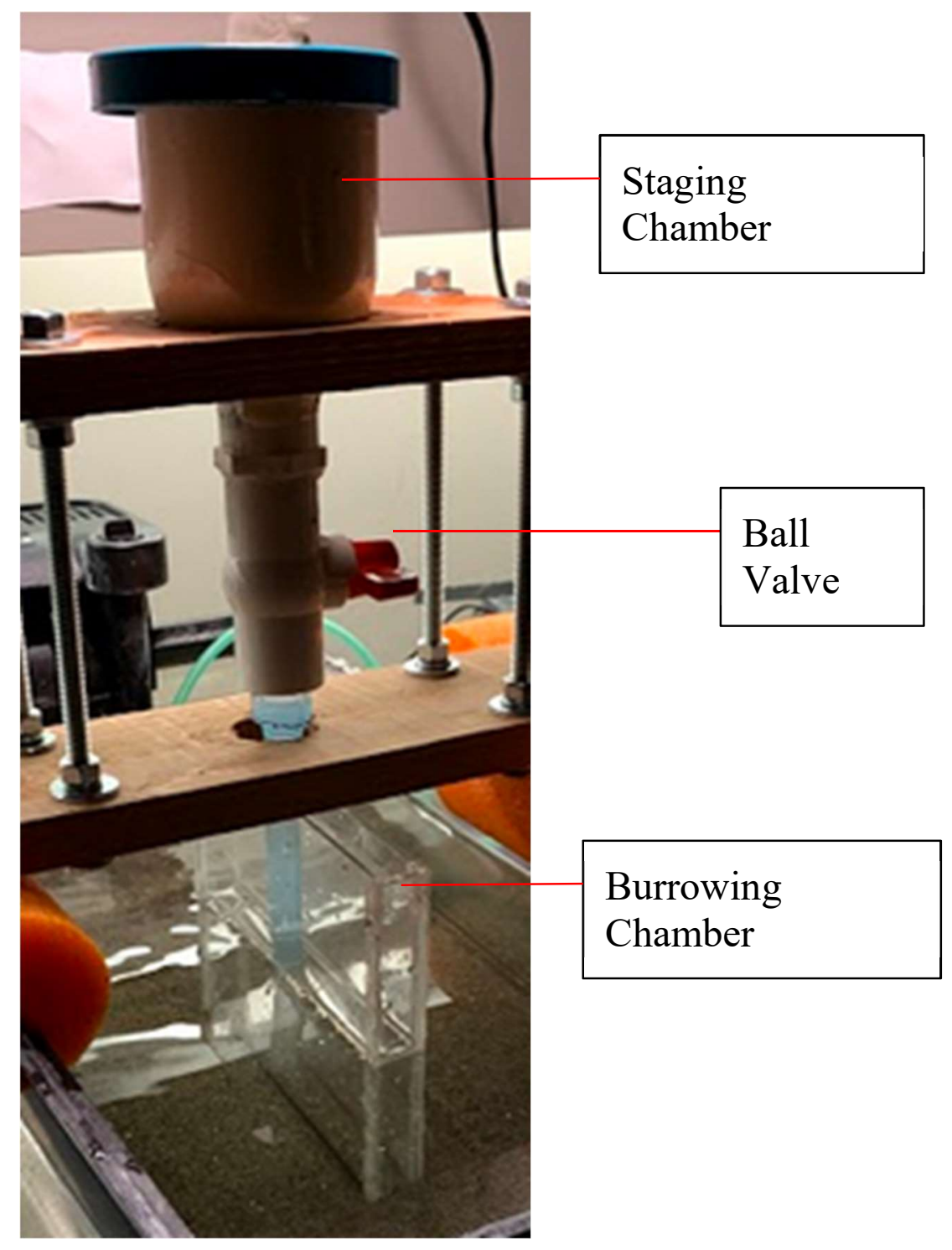

Figure 3: The staging chamber (top) was a covered, opaque container filled with $150 \mathrm{ml}$ of water from the burrowing trial tank. After staging, the valve (middle) was turned to release the water, guiding the lamprey through the tube and into the acrylic chamber of the burrowing aquarium (bottom). 


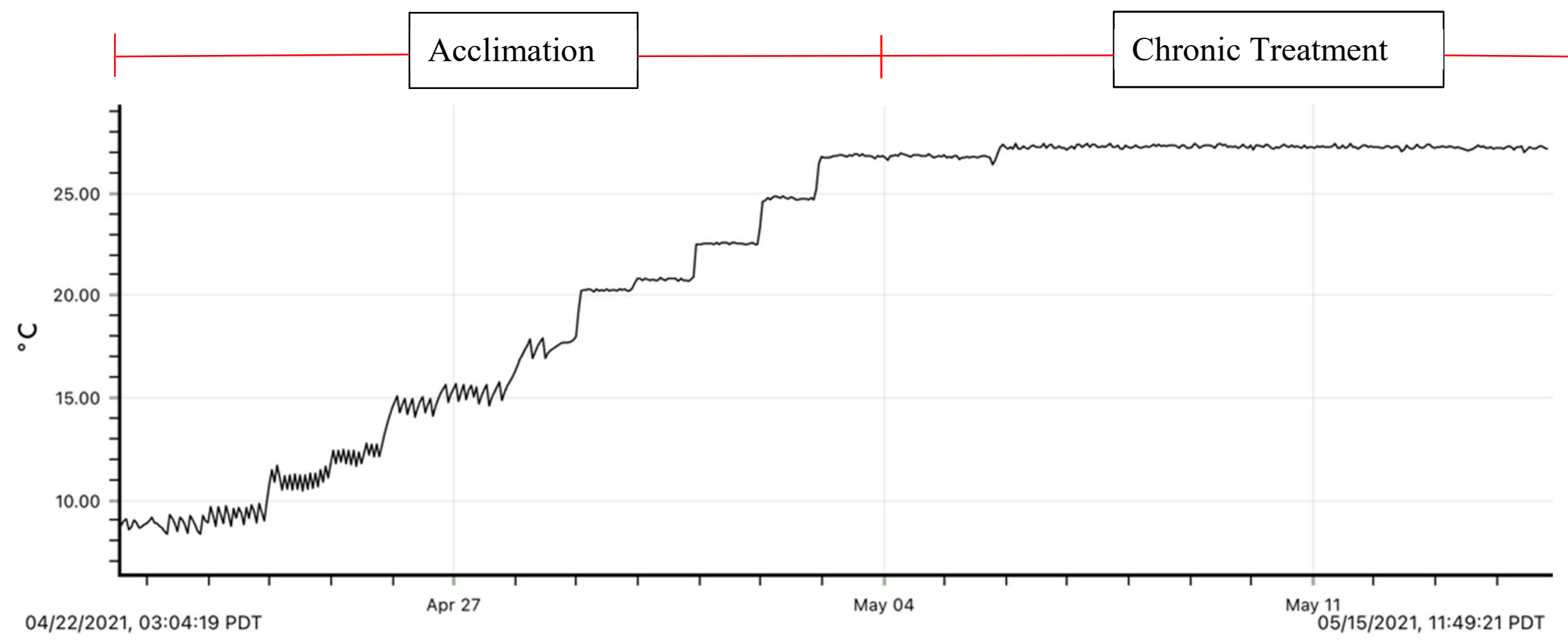

Figure 4: Water temperature from time of collection (April 22, 2021) to end of chronic treatments (May 15th, 2021). Transfer from acclimation period to chronic temperature treatments took place on May 4th, 2021. Temperatures were maintained between $1{ }^{\circ} \mathrm{C}$ of target temperature $\left(27^{\circ} \mathrm{C}\right)$ from the end of the acclimation period (May 4th, 2021) to the end of the chronic treatment period (May 14th, 2021). 


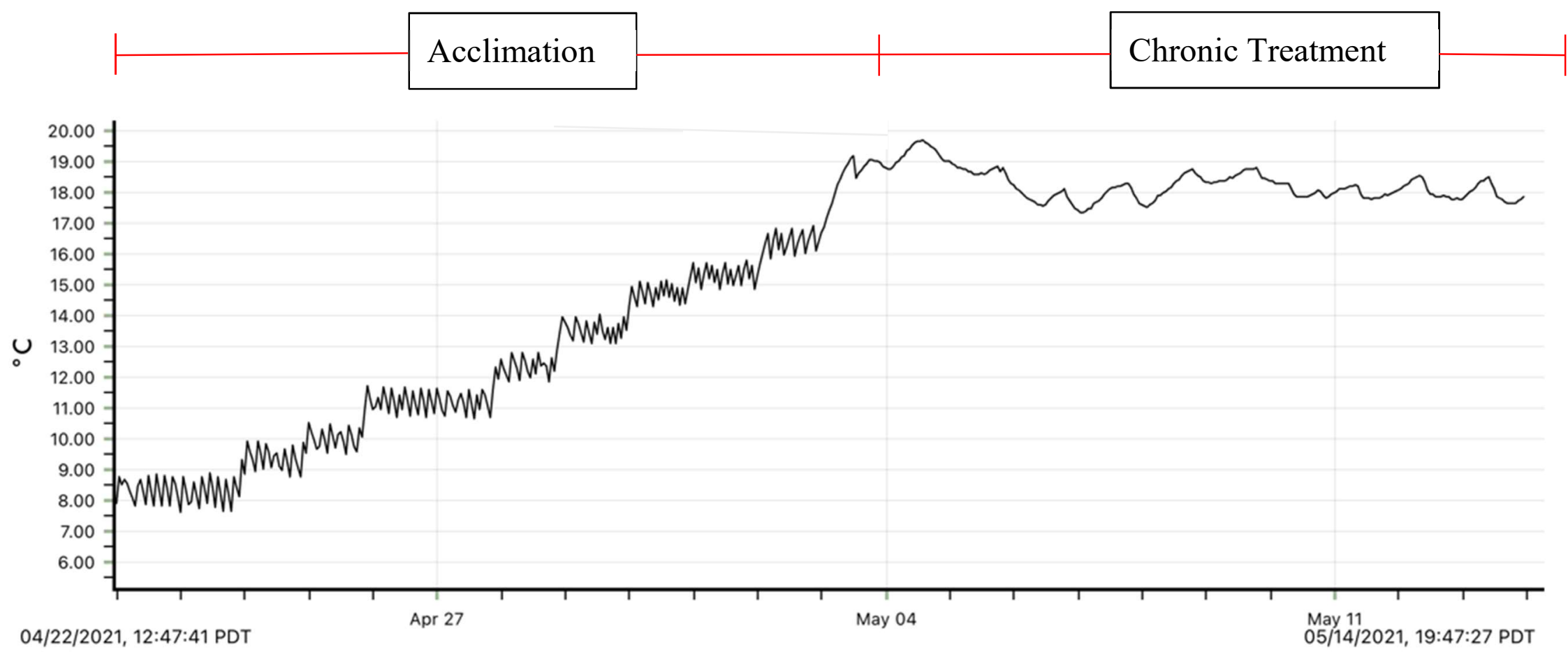

Figure 5: Water temperature data from collection (April 22, 2021) to end of chronic treatments (May 15th, 2021). Transfer from acclimation period to chronic temperature treatments took place on May 4th, 2021. Temperatures were maintained between $2^{\circ} \mathrm{C}$ of target temperature $\left(18^{\circ} \mathrm{C}\right)$ from the end of the acclimation period (May 4th, 2021) to the end of the chronic treatment period (May 14th, 2021). 


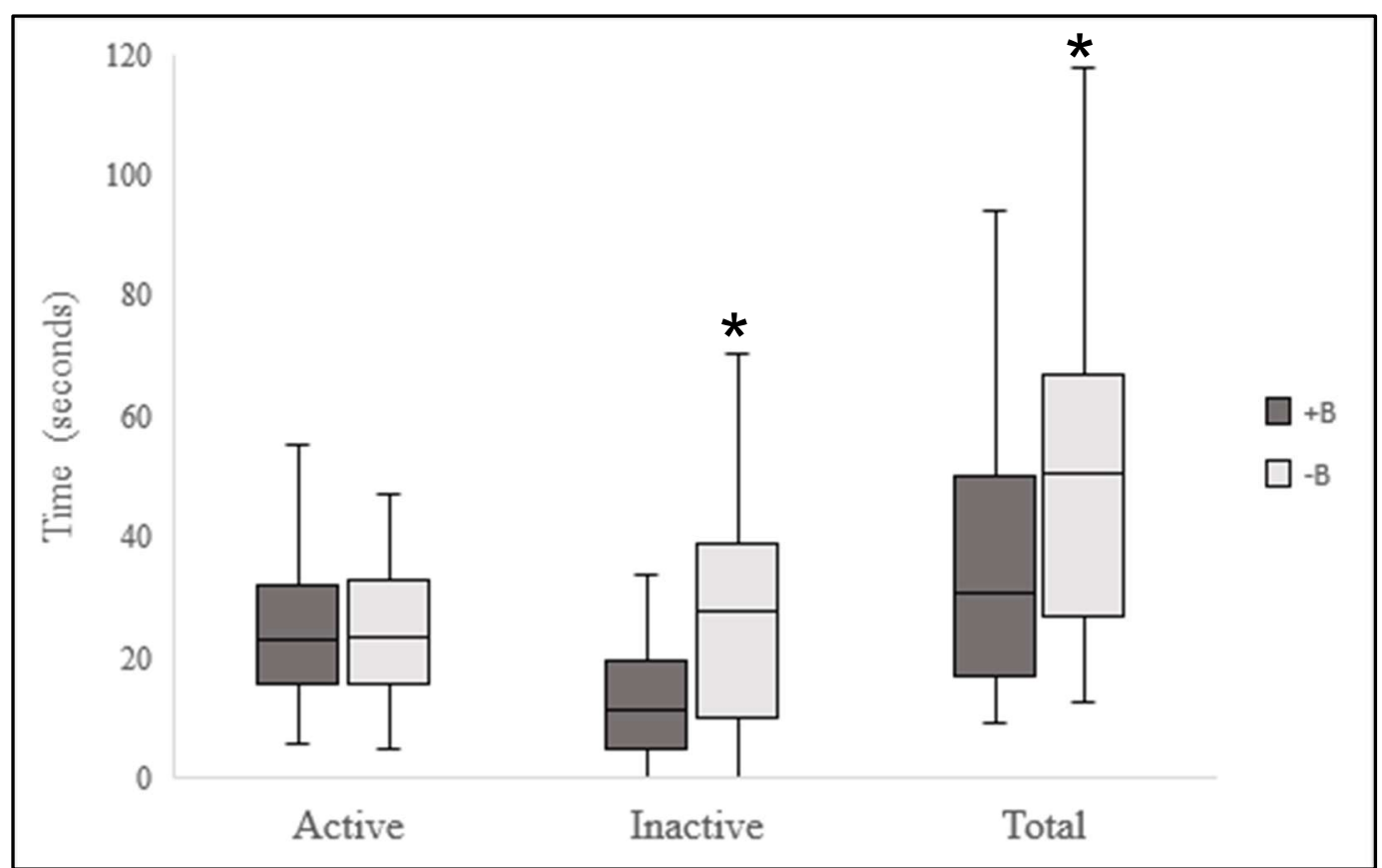

Figure 6: Comparisons of burrowing groups for active burrowing time, inactive burrowing time, and total burrowing time. Significant differences are indicated with an asterisk.

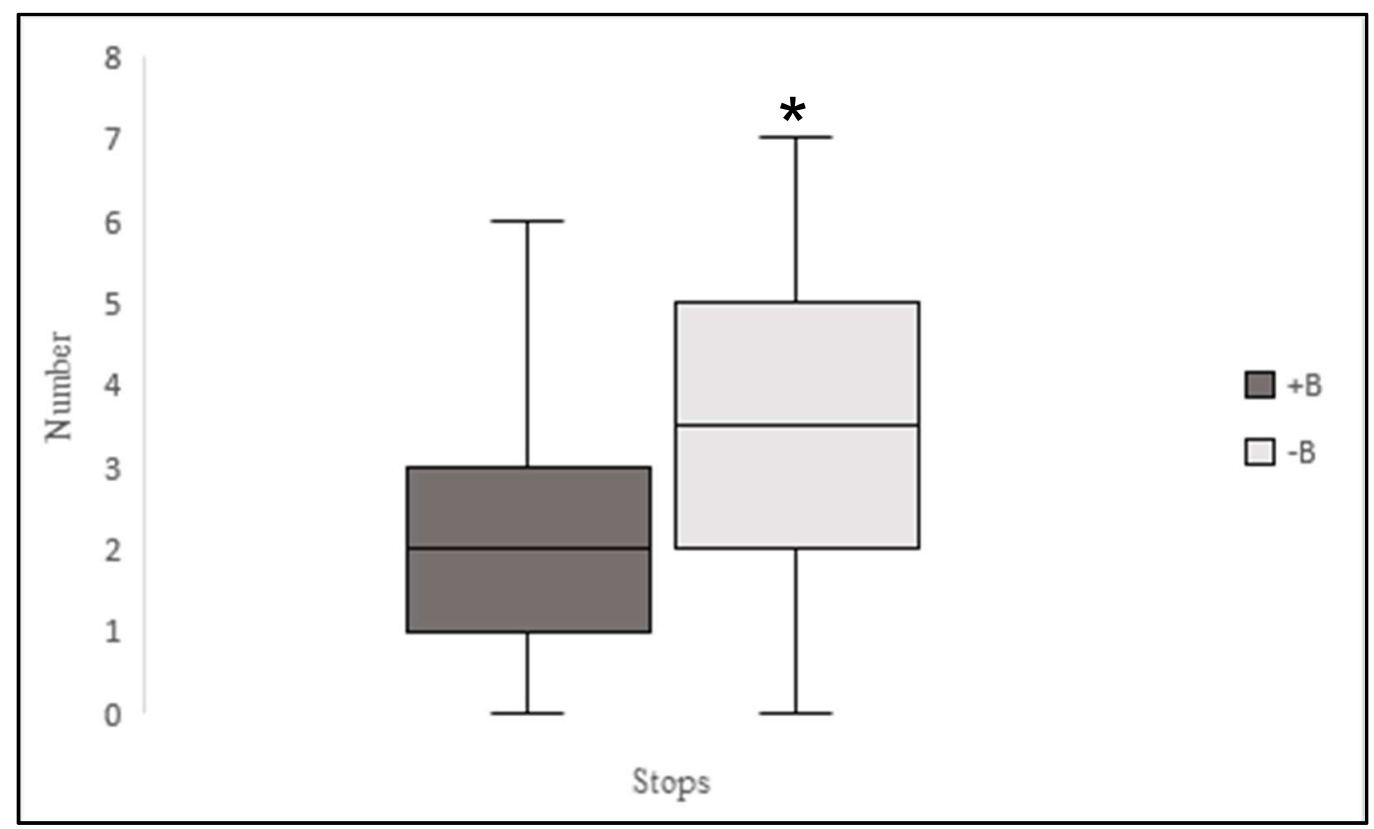

Figure 6a: Comparisons of burrowing groups for number of stops. Significant differences are indicated with an asterisk. 


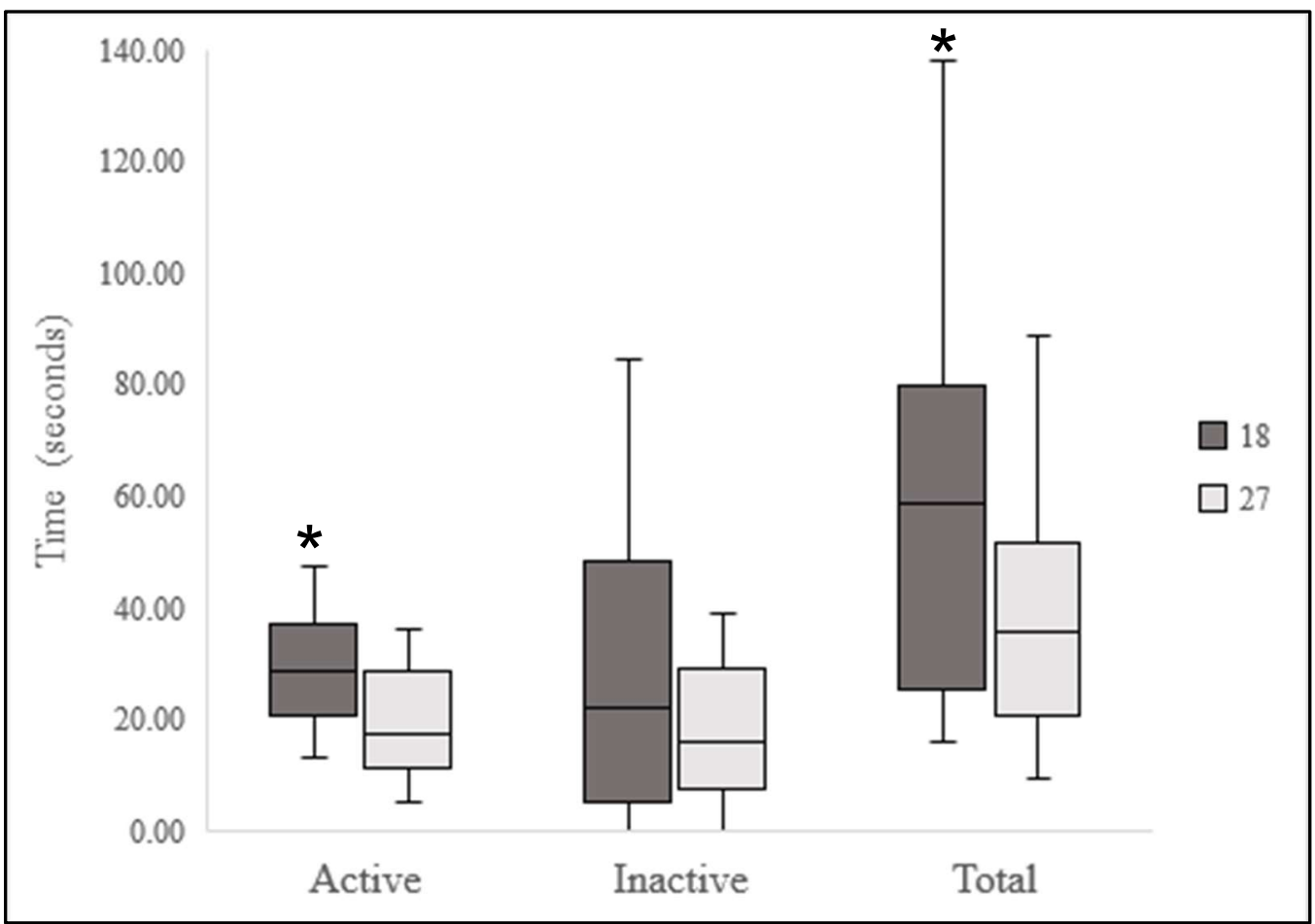

Figure 7: Box and whisker plots of active burrowing time (Active), inactive burrowing time (Inactive), and total burrowing time (Total) for temperature treatments $\left(18^{\circ} \mathrm{C}, 27^{\circ} \mathrm{C}\right)$. Significant differences are indicated with an asterisk.

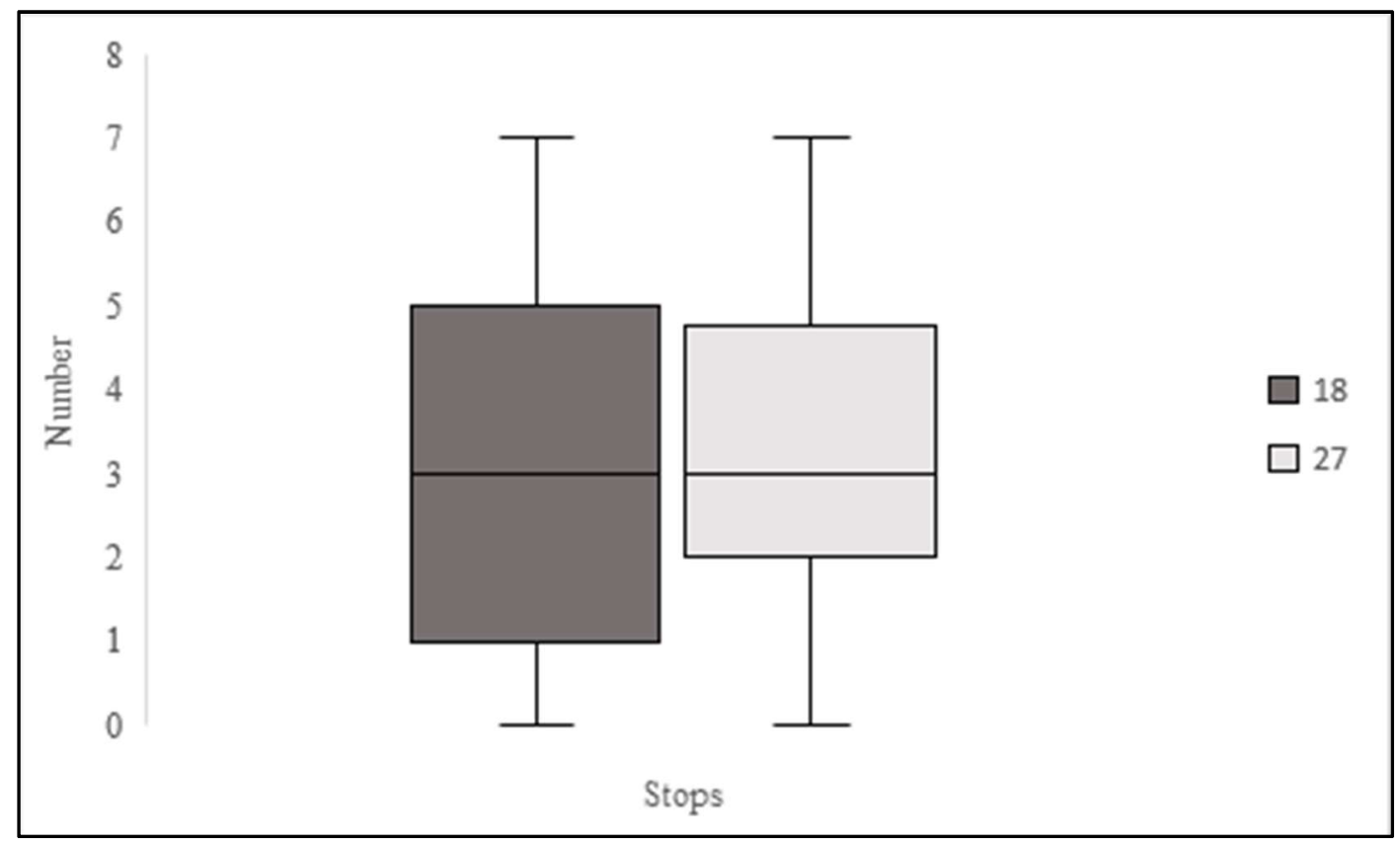

Figure 7a: Comparison of temperature groups for number of stops. 


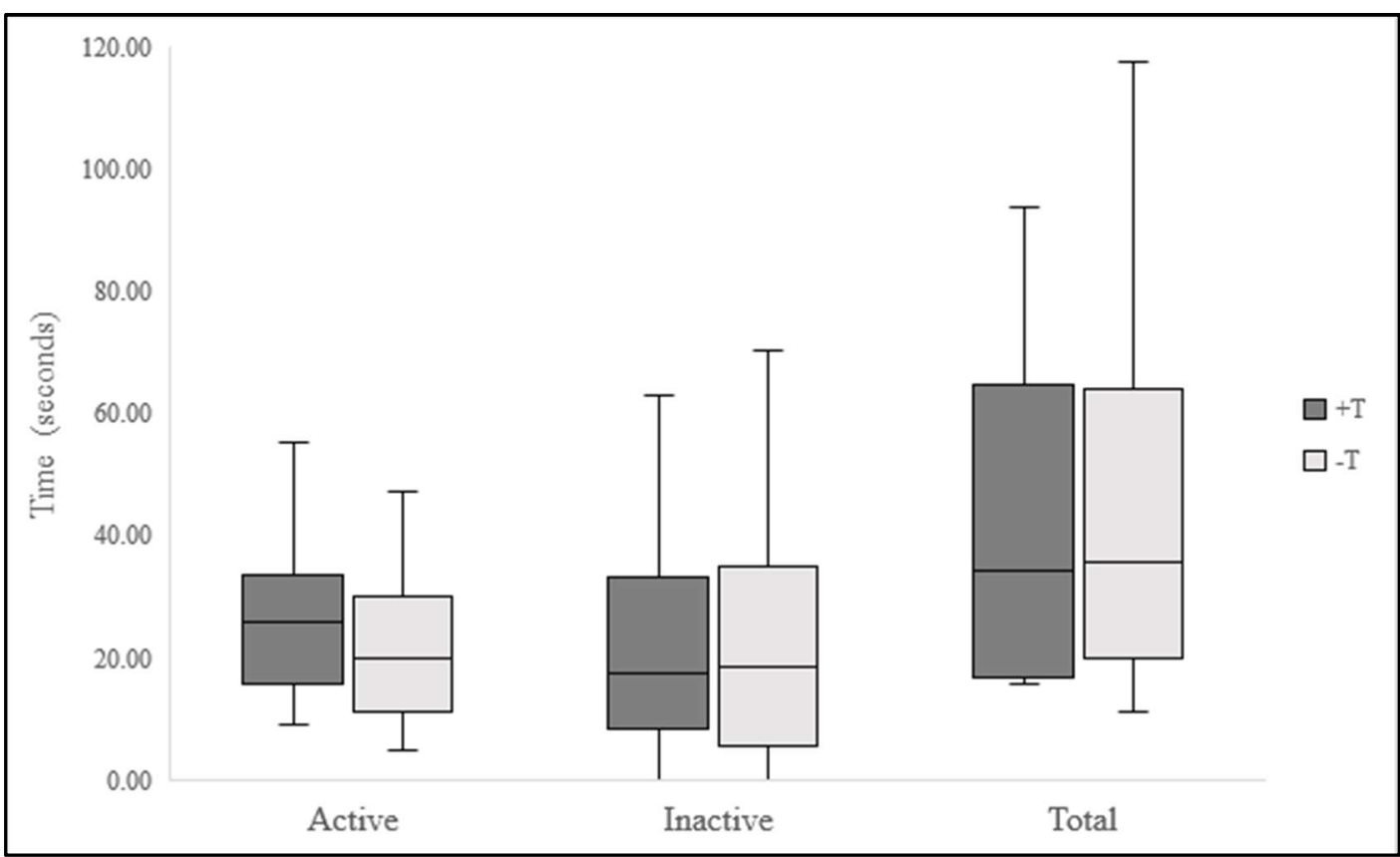

Figure 8: Box and whisker plots of turbulent flow treatments for active burrowing time, inactive burrowing time, and total burrowing time. Presence of flow is indicated by $(+\mathrm{T})$ and absence of flow is indicated by $(-\mathrm{T})$

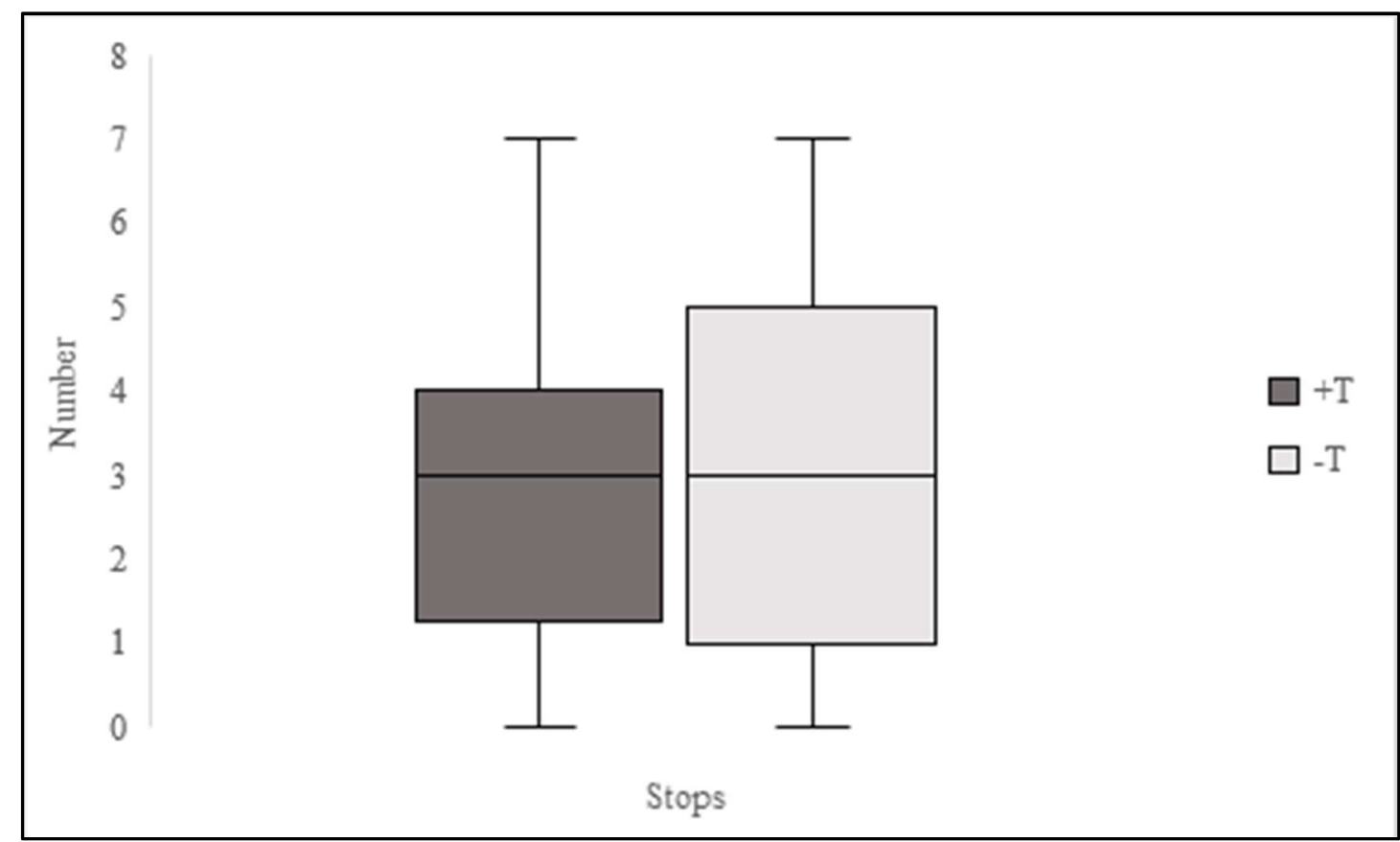

Figure 8a: Comparison of turbulent flow groups for number of stops. Presence of flow is indicated by $(+\mathrm{T})$ and absence of flow is indicated by $(-\mathrm{T})$. 


\section{TABLES}

\begin{tabular}{|c|c|c|c|c|}
\hline $\begin{array}{c}\text { Tank } \\
\text { Number }\end{array}$ & $\begin{array}{c}\text { Sample Size } \\
\text { (n) }\end{array}$ & Temperature & Turbulent Flow & Burrowing Ability \\
\hline 1 & 11 & $18^{\circ} \mathrm{C}$ & $-\mathrm{T}$ & $-\mathrm{B}$ \\
\hline 2 & 12 & $27^{\circ} \mathrm{C}$ & $+\mathrm{T}$ & $+\mathrm{B}$ \\
\hline 3 & 11 & $27^{\circ} \mathrm{C}$ & $+\mathrm{T}$ & $-\mathrm{B}$ \\
\hline 4 & 9 & $18^{\circ} \mathrm{C}$ & $+\mathrm{T}$ & $+\mathrm{B}$ \\
\hline 5 & 8 & $18^{\circ} \mathrm{C}$ & $+\mathrm{T}$ & $-\mathrm{B}$ \\
\hline 6 & 12 & $27^{\circ} \mathrm{C}$ & $-\mathrm{T}$ & $-\mathrm{B}$ \\
\hline
\end{tabular}

Table 1: All treatments with conditions of temperature, turbulence, and burrowing ability described for each aquarium. Temperatures for each aquarium are described as $18^{\circ} \mathrm{C}$ or $27^{\circ} \mathrm{C}$. Turbulent flow is indicated as present $(+\mathrm{T})$ or absent $(-\mathrm{T})$, and burrowing ability is indicated as present $(+\mathrm{B})$ or prevented $(-\mathrm{B})$. 


\begin{tabular}{|c|c|c|c|c|c|c|}
\hline $\begin{array}{l}\text { Treatment } \\
\text { Combination }\end{array}$ & Comparison & $\begin{array}{l}\text { Sample Size } \\
\text { (n) }\end{array}$ & Metric & Median & $\begin{array}{c}\text { Range } \\
\text { (Min, Max) }\end{array}$ & $\mathbf{P}$ \\
\hline$+\mathrm{T} /+\mathrm{B} / 18^{\circ} \mathrm{C}$ & \multirow{8}{*}{1} & 9 & \multirow[t]{2}{*}{ Active Time } & 22.93 & $13.00,42.55$ & \multirow{2}{*}{0.4300} \\
\hline$+\mathrm{T} /+\mathrm{B} / 27^{\circ} \mathrm{C}$ & & 12 & & 24.99 & $9.270,55.10$ & \\
\hline$+\mathrm{T} /+\mathrm{B} / 18^{\circ} \mathrm{C}$ & & 9 & \multirow{2}{*}{ Inactive Time } & 9.200 & $0.000,55.77$ & \multirow{2}{*}{0.7200} \\
\hline$+\mathrm{T} /+\mathrm{B} / 27^{\circ} \mathrm{C}$ & & 12 & & 12.55 & $0.000,33.50$ & \\
\hline$+\mathrm{T} /+\mathrm{B} / 18^{\circ} \mathrm{C}$ & & 9 & \multirow{2}{*}{ Total Time } & 34.26 & $15.78,93.80$ & \multirow{2}{*}{0.8900} \\
\hline$+\mathrm{T} /+\mathrm{B} / 27^{\circ} \mathrm{C}$ & & 12 & & 33.72 & $9.27,88.51$ & \\
\hline$+\mathrm{T} /+\mathrm{B} / 18^{\circ} \mathrm{C}$ & & 9 & \multirow{2}{*}{$\begin{array}{l}\text { Number of } \\
\text { Stops }\end{array}$} & 1.000 & $0.000,6.000$ & \multirow{2}{*}{0.3400} \\
\hline$+\mathrm{T} /+\mathrm{B} / 27^{\circ} \mathrm{C}$ & & 12 & & 2.500 & $0.000,7.000$ & \\
\hline$+\mathrm{T} /-\mathrm{B} / 18^{\circ} \mathrm{C}$ & \multirow{4}{*}{2} & 8 & \multirow{2}{*}{ Active Time } & 32.34 & $20.50,41.86$ & \multirow{2}{*}{0.0130} \\
\hline$+\mathrm{T} /-\mathrm{B} / 27^{\circ} \mathrm{C}$ & & 11 & & 17.28 & $10.56,34.61$ & \\
\hline$+\mathrm{T} /-\mathrm{B} / 18^{\circ} \mathrm{C}$ & & 8 & & 34.35 & $4.800,70.41$ & \multirow{2}{*}{0.1600} \\
\hline$+\mathrm{T} /-\mathrm{B} / 27^{\circ} \mathrm{C}$ & & 11 & & 27.80 & $4.000,37.22$ & \\
\hline
\end{tabular}




\begin{tabular}{|c|c|c|c|c|c|c|}
\hline$+\mathrm{T} /-\mathrm{B} / 18^{\circ} \mathrm{C}$ & & 8 & \multirow{2}{*}{ Total Time } & 66.49 & $25.30,112.3$ & \multirow{2}{*}{0.0390} \\
\hline$+\mathrm{T} /-\mathrm{B} / 27^{\circ} \mathrm{C}$ & & 11 & & 46.40 & $18.78,62.85$ & \\
\hline$+\mathrm{T} /-\mathrm{B} / 18^{\circ} \mathrm{C}$ & & 8 & \multirow{2}{*}{$\begin{array}{l}\text { Number of } \\
\text { Stops }\end{array}$} & 3.500 & $1.000,7.000$ & \multirow{2}{*}{0.7400} \\
\hline$+\mathrm{T} /-\mathrm{B} / 27^{\circ} \mathrm{C}$ & & 11 & & 4.000 & $1.000,5.000$ & \\
\hline$-\mathrm{T} /-\mathrm{B} / 18^{\circ} \mathrm{C}$ & \multirow{8}{*}{3} & 11 & \multirow{2}{*}{ Active Time } & 30.03 & $19.08,67.80$ & \multirow{2}{*}{$0.0009^{*}$} \\
\hline$-\mathrm{T} /-\mathrm{B} / 27^{\circ} \mathrm{C}$ & & 6 & & 13.94 & $4.980,18.94$ & \\
\hline$-\mathrm{T} /-\mathrm{B} / 18^{\circ} \mathrm{C}$ & & 11 & \multirow{2}{*}{ Inactive Time } & 20.40 & $0.000,84.35$ & \multirow{2}{*}{0.9900} \\
\hline$-\mathrm{T} / \mathrm{-B} / 27^{\circ} \mathrm{C}$ & & 6 & & 20.40 & $7.520,39.20$ & \\
\hline$-\mathrm{T} /-\mathrm{B} / 18^{\circ} \mathrm{C}$ & & 11 & \multirow{2}{*}{ Total Time } & 64.00 & $20.10,138.1$ & \multirow{2}{*}{0.2700} \\
\hline$-\mathrm{T} / \mathrm{-B} / 27^{\circ} \mathrm{C}$ & & 6 & & 32.80 & $12.50,57.93$ & \\
\hline$-\mathrm{T} /-\mathrm{B} / 18^{\circ} \mathrm{C}$ & & 11 & \multirow{2}{*}{$\begin{array}{l}\text { Number of } \\
\text { Stops }\end{array}$} & 2.000 & $0.000,7.000$ & \multirow{2}{*}{0.4500} \\
\hline$-\mathrm{T} / \mathrm{-B} / 27^{\circ} \mathrm{C}$ & & 6 & & 3.500 & $2.000,5.000$ & \\
\hline$+\mathrm{T} /+\mathrm{B} / 18^{\circ} \mathrm{C}$ & & 9 & \multirow{2}{*}{ Active Time } & 22.93 & $13.00,42.55$ & \multirow{2}{*}{0.1000} \\
\hline$+\mathrm{T} /-\mathrm{B} / 18^{\circ} \mathrm{C}$ & & 8 & & 32.34 & $20.50,41.86$ & \\
\hline
\end{tabular}




\begin{tabular}{|c|c|c|c|c|c|c|}
\hline$+\mathrm{T} /+\mathrm{B} / 18^{\circ} \mathrm{C}$ & \multirow{6}{*}{4} & 9 & \multirow{2}{*}{ Inactive Time } & 9.200 & $0,55.77$ & \multirow{2}{*}{0.0400} \\
\hline$+\mathrm{T} /-\mathrm{B} / 18^{\circ} \mathrm{C}$ & & 8 & & 34.35 & $4.800,70.41$ & \\
\hline$+\mathrm{T} /+\mathrm{B} / 18^{\circ} \mathrm{C}$ & & 9 & \multirow{2}{*}{ Total Time } & 34.26 & $15.78,93.80$ & \multirow{2}{*}{0.0500} \\
\hline$+\mathrm{T} /-\mathrm{B} / 18^{\circ} \mathrm{C}$ & & 8 & & 66.49 & $25.30,112.3$ & \\
\hline$+\mathrm{T} /+\mathrm{B} / 18^{\circ} \mathrm{C}$ & & 9 & \multirow{2}{*}{$\begin{array}{l}\text { Number of } \\
\text { Stops }\end{array}$} & 1.000 & $0,6.000$ & \multirow{2}{*}{0.0300} \\
\hline$+\mathrm{T} /-\mathrm{B} / 18^{\circ} \mathrm{C}$ & & 8 & & 3.500 & $1.000,7.000$ & \\
\hline$+\mathrm{T} /+\mathrm{B} / 27^{\circ} \mathrm{C}$ & \multirow{8}{*}{5} & 12 & \multirow{2}{*}{ Active Time } & 24.99 & $9.270,55.10$ & \multirow{2}{*}{0.1100} \\
\hline$+\mathrm{T} /-\mathrm{B} / 27^{\circ} \mathrm{C}$ & & 11 & & 17.28 & $10.56,34.61$ & \\
\hline$+\mathrm{T} /+\mathrm{B} / 27^{\circ} \mathrm{C}$ & & 12 & \multirow{2}{*}{ Inactive Time } & 12.55 & $0,33.50$ & \multirow{2}{*}{$0.0590 \mathrm{C}$} \\
\hline$+\mathrm{T} /-\mathrm{B} / 27^{\circ} \mathrm{C}$ & & 11 & & 27.80 & $4.000,37.22$ & \\
\hline$+\mathrm{T} /+\mathrm{B} / 27^{\circ} \mathrm{C}$ & & 12 & \multirow{2}{*}{ Total Time } & 33.715 & $9.270,88.51$ & \multirow{2}{*}{0.6200} \\
\hline$+\mathrm{T} /-\mathrm{B} / 27^{\circ} \mathrm{C}$ & & 11 & & 46.40 & $18.78,62.85$ & \\
\hline$+\mathrm{T} /+\mathrm{B} / 27^{\circ} \mathrm{C}$ & & 12 & \multirow{2}{*}{$\begin{array}{l}\text { Number of } \\
\text { Stops }\end{array}$} & 2.500 & $0,7.000$ & \multirow{2}{*}{0.2700} \\
\hline$+\mathrm{T} /-\mathrm{B} / 27^{\circ} \mathrm{C}$ & & 11 & & 4.000 & $1.000,5.000$ & \\
\hline
\end{tabular}




\begin{tabular}{|c|c|c|c|c|c|c|}
\hline$+\mathrm{T} /-\mathrm{B} / 27^{\circ} \mathrm{C}$ & \multirow{8}{*}{6} & 11 & \multirow{2}{*}{ Active Time } & 17.28 & $10.56,34.61$ & \multirow{2}{*}{0.3700} \\
\hline$-\mathrm{T} /-\mathrm{B} / 27^{\circ} \mathrm{C}$ & & 6 & & 13.94 & $4.980,18.94$ & \\
\hline$+\mathrm{T} /-\mathrm{B} / 27^{\circ} \mathrm{C}$ & & 11 & \multirow{2}{*}{ Inactive Time } & 27.80 & $4.000,37.22$ & \multirow{2}{*}{0.8400} \\
\hline$-\mathrm{T} /-\mathrm{B} / 27^{\circ} \mathrm{C}$ & & 6 & & 20.40 & $7.520,39.20$ & \\
\hline$+\mathrm{T} /-\mathrm{B} / 27^{\circ} \mathrm{C}$ & & 11 & \multirow{2}{*}{ Total Time } & 46.40 & $18.78,62.85$ & \multirow{2}{*}{0.4810} \\
\hline$-\mathrm{T} /-\mathrm{B} / 27^{\circ} \mathrm{C}$ & & 6 & & 32.795 & $12.50,57.93$ & \\
\hline$+\mathrm{T} /-\mathrm{B} / 27^{\circ} \mathrm{C}$ & & 11 & \multirow{2}{*}{$\begin{array}{l}\text { Number of } \\
\text { Stops }\end{array}$} & 4.000 & $1.000,5.000$ & \multirow{2}{*}{0.8000} \\
\hline$-\mathrm{T} /-\mathrm{B} / 27^{\circ} \mathrm{C}$ & & 6 & & 3.500 & $2.000,5.000$ & \\
\hline$+\mathrm{T} /-\mathrm{B} / 18^{\circ} \mathrm{C}$ & \multirow{6}{*}{7} & 8 & \multirow{2}{*}{ Active Time } & 32.34 & $20.50,41.86$ & \multirow{2}{*}{0.4100} \\
\hline$-\mathrm{T} /-\mathrm{B} / 18^{\circ} \mathrm{C}$ & & 11 & & 30.03 & $19.08,67.80$ & \\
\hline$+\mathrm{T} /-\mathrm{B} / 18^{\circ} \mathrm{C}$ & & 8 & \multirow{2}{*}{ Inactive Time } & 34.35 & $4.800,70.41$ & \multirow{2}{*}{0.5100} \\
\hline$-\mathrm{T} /-\mathrm{B} / 18^{\circ} \mathrm{C}$ & & 11 & & 20.40 & $0,84.35$ & \\
\hline$+\mathrm{T} /-\mathrm{B} / 18^{\circ} \mathrm{C}$ & & 8 & \multirow{2}{*}{ Total Time } & 66.49 & $25.30,112.3$ & \multirow{2}{*}{0.6200} \\
\hline$-\mathrm{T} /-\mathrm{B} / 18^{\circ} \mathrm{C}$ & & 11 & & 64.00 & $20.10,138.2$ & \\
\hline
\end{tabular}




\begin{tabular}{|c|c|c|c|c|c|c|}
\hline$+\mathrm{T} /-\mathrm{B} / 18^{\circ} \mathrm{C}$ & & 8 & & 3.500 & $1.000,7.000$ & \\
\hline$-\mathrm{T} /-\mathrm{B} / 18^{\circ} \mathrm{C}$ & & 11 & & 2.000 & $0,7.000$ & \\
\hline$+\mathrm{T} /+\mathrm{B} / 18^{\circ} \mathrm{C}$ & \multirow{8}{*}{8} & 9 & \multirow{2}{*}{ Active Time } & 22.93 & $13.00,42.55$ & \multirow{2}{*}{0.2700} \\
\hline$+\mathrm{T} /-\mathrm{B} / 27^{\circ} \mathrm{C}$ & & 11 & & 17.28 & $10.56,34.61$ & \\
\hline$+\mathrm{T} /+\mathrm{B} / 18^{\circ} \mathrm{C}$ & & 9 & \multirow{2}{*}{ Inactive Time } & 9.200 & $0,55.77$ & \multirow{2}{*}{0.08900} \\
\hline$+\mathrm{T} /-\mathrm{B} / 27^{\circ} \mathrm{C}$ & & 11 & & 27.80 & $4.000,37.22$ & \\
\hline$+\mathrm{T} /+\mathrm{B} / 18^{\circ} \mathrm{C}$ & & 9 & \multirow{2}{*}{ Total Time } & 34.26 & $15.78,93.80$ & \multirow{2}{*}{0.5700} \\
\hline$+\mathrm{T} /-\mathrm{B} / 27^{\circ} \mathrm{C}$ & & 11 & & 46.40 & $18.78,62.85$ & \\
\hline$+\mathrm{T} /+\mathrm{B} / 18^{\circ} \mathrm{C}$ & & 9 & \multirow{2}{*}{$\begin{array}{l}\text { Number of } \\
\text { Stops }\end{array}$} & 1.000 & $0,6.000$ & \multirow{2}{*}{0.04999} \\
\hline$+\mathrm{T} /-\mathrm{B} / 27^{\circ} \mathrm{C}$ & & 11 & & 4.000 & $1.000,5.000$ & \\
\hline
\end{tabular}

Table 2: Eight planned comparisons between various treatments. Each group being compared, one of four metrics, the range in seconds Significant P-values are indicated with an asterisk. 


\section{LITERATURE CITED}

Arakawa, H. and R. T. Lampman. 2020. An experimental study to evaluate predation threats on two native larval lampreys in the Columbia River Basin, USA. Ecology of Freshwater Fish 29:611612.

Bracken, F. S. A. and Lucas, M. C. 2013. Potential impacts of small-scale hydroelectric power generation on downstream moving lampreys. River Research and Applications. 29:1073-1081.

Claireaux, G., C. Couturier, and A. Groison. 2006. Effect of temperature on maximum swimming speed and cost of transport in juvenile European sea bass (Dicentrarchus labrax). Journal of Experimental Biology. 209:3420-3428.

Clemens, B. J., R. J. Beamish, K. C. Coates, M. F. Docker, J. B. Dunham, A. E. Gray, J. E. Hess, J. C. Jolley, R. T. Lampman, B. J. McIlraith, M. L. Moser, J. G. Murauskas, D. L. G. Noakes, H. A. Schaller, C. B. Schreck, S. J. Starcevich, B. Streif, S. J. van de Wetering, J. Wade, L. A. Weitkamp, and L. A. Wyss. 2017. Conservation challenges and research needs for Pacific lamprey in the Columbia River Basin. Fisheries 42:268-280.

Clemens, B. J., L. Weitkamp, K. Siwicke, J. Wade, J. Harris, J. Hess, L. Porter, K. Parker, T. Sutton and A. Orlov. 2019. Marine biology of the pacific lamprey Entosphenus tridentatus. Reviews in Fish Biology and Fisheries 29:767-788.

Close, D. A., M. Fitzpatrick, H. Li, B. L. Parker, D. R. Hatch, and G. James. 1995. Status report of the Pacific lamprey (Lampetra tridentata) in the Columbia basin. Bonneville Power Administration Report, Project Number 94-026, Portland, OR

Close, D. A., M. S. Fitzpatrick, and H. W. Li. 2002. The ecological and cultural importance of a species at risk of extinction, Paicific lamprey. Fisheries 27:19-25.

Dauble, D. D., R. A. Moursund, and M. D. Bleich. 2006. Swimming behavior of juvenile Pacific lamprey, Lampetra tridentata. Environmental Biology of Fishes 75:167-171.

Dawson, H. A., D. D. Potts, A. C. Maguffee, and L. M. O’Connor. 2015a. Feasibility of passive integrated transponder technology to study in situ movements of larval sea lamprey. Journal of Fish and Wildlife Management 6:71-82.

Dawson, H. A. B. R. Quintella, P. R. Almeida, A. J. Treble, and J. J. Jolley. 2015b. The ecology of larval and metamorphosing lampreys. In Docker M. (editor) Lampreys: Biology, Conservation, and Control. Fish and Fisheries Series. Colorado Parks and Wildlife, Aquatic Research Unit. Fort Collins, Colorado. 37:75-137.

Docker, M. F., G. S. Silver, J. C. Jolley, and E. K. Spice. 2016. Simple genetic assay distinguishes lamprey genera Entosphenus and Lampetra: Comparison with existing genetic and morphological identification methods. North American Journal of Fisheries Management 36:780-787

Ficklin, D. L., B. L. Barnhart, J. H. Knouft, I. T. Stewart, E. P. Maurer, S. L. Letsinger, and G. W. Whittaker. 2014. Climate change projections and stream temperature projections in the Columbia River basin: habitat implications of spatial variation in hydrologic drivers. Hydrology and Earth System Sciences 18:4897-4912. 
Harris, J. E., J. J. Skalicky, T. L. Liedtke, L. K. Weiland, B. J. Clemens, and A. E. Gray. 2020. Effects of dewatering on behavior, distribution, and abundance of larval lampreys. River Research and Applications 36:2001-2012.

Jolley, J. C., C. T. Uh, G. S. Silver, and T. A. Whitesel. 2015. Feeding and growth of larval Pacific lamprey reared in captivity. North American Journal of Aquaculture 77:4, 449-459

Kostow, K. 2002. Oregon lampreys: Natural history, Status, and Analysis of Management Issues. Oregon Department of Fish and Wildlife. Portland, Oregon.

McClellan, A. D., T. Pale, J. A. Messina, S. Buso, and A. Shebib. 2016. Similarities and differences for swimming in larval and adult lampreys. Physiological and Biochemical Zoology. 89:294-312.

Merz, M. J. Palmer, and A. Clayton. 2019. Longitudinal Temperature Variability in the Lower Columbia River. 2019. A Draft Technical Memorandum on the Characterization of Columbia River Temperature Variability. Environmental Protection Agency. Available from https://www.epa.gov/sites/default/files/2019-09/documents/columbia-river-cwr-plan-appendix1.pdf

Ostberg, C. O., D. M. Chase, M. S. Hoy, J. J. Duda, M. C. Hayes, J. J. Jolley, G. S. Silver, and C. CookTabor. 2019. Evaluation of environmental DNA surveys for identifying occupancy and spatial distribution of pacific lamprey (Entosphenus tridentatus) and Lampetra spp. in a Washington coast watershed. Environmental DNA 2:131-143

Potter, I. C. and M. J. Rogers. 1972. Oxygen consumption in burrowed and unburrowed ammocoetes of Lampetra planeri. Comparative Biochemistry and Physiology. 41:427-432.

Quintella, B. R., N. No. Andrade, N. M. Dias, P. R. Almeida. 2007. Laboratory assessment of sea lamprey larvae burrowing performance. Ecology of Freshwater Fish 16:177-182

Renaud, C. B. 2011. Lampreys of the World: an Annotated and Illustrated Catalogue of Lamprey Species Known to Date. Food and Agriculture Organization of the United Nations (FAO) Species Catalogue for Fishery Purposes. Rome, Italy.

Riyanto, M., K. Yanase, and T. Tokyo. 2014. Temperature and fatigue effect on the maximum swimming speed of jack mackerel Trachurus japonicus. Fisheries Science. 80:53-59

Sutphin, Z. A. and C. D. Heuth. 2010. Swimming performance of larval Pacific lamprey (Lampetra tridentata). Northwest Science 84:196-200.

Temple, G. K. and I. A. Johnston. 1997. The thermal dependence of fast-start performance in fish. Journal of Thermal Biology. 22:391-401.

Uh, C. T. and T. A. Whitesel. 2017. Evidence that the upper thermal tolerance limit of larval Pacific lamprey falls between $27^{\circ} \mathrm{C}$ and $29^{\circ} \mathrm{C}$. Unpublished report on file at U. S. Fish and Wildlife Service Columbia River Fisheries Conservation Office, Vancouver, Washington.

USFWS (U.S. Fish and Wildlife Service). 2004. Endangered and threatened wildlife and plants; 90 day finding on a petition to list three species of lampreys as threatened or endangered. Federal Register 69:77158-77167.

USFWS (U.S. Fish and Wildlife Service). 2012. Pacific Lamprey Conservation Agreement. U. S. Fish and Wildlife Service, Portland Oregon. 
Wang, C., and H. Schaller. 2015. Conserving Pacific lamprey through collaborative efforts. Fisheries 40:72-79

Wang, C. J., H. A. Schaller, K. C. Coates, M. C. Hayes, and R. K. Rose. 2020. Climate change and vulnerability assessment for Pacific lamprey in rivers of the Western United States. Journal of Freshwater Ecology 35:29-55.

Wilkie, M. P., P. G. Bradshaw, V. Joanis, J. F. Claude, and S. L. Swindell. 2001. Rapid metabolic recovery following vigorous exercise in burrow-dwelling larval sea lampreys (Petromyzon marinus). Physiological and Biochemical Zoology 74:261-272. 